\section{Influence of Cultivar and Seasonal Growing Environment on Growth and Postharvest Characteristics of Single-shoot Pot Rose Plants}

\author{
José Antonio Saraiva Grossi ${ }^{1}$ and H. Brent Pemberton ${ }^{2}$ \\ Texas A\&M University Agricultural Research and Extension Center, P.O. Box \\ 200, Overton, TX 75684
}

\author{
Harvey J. Lang ${ }^{3}$ \\ TX 77843-2133 \\ Additional index words. miniature rose, Rosa, flower longevity
}

Department of Horticultural Sciences, Texas A\&M University, College Station,

\begin{abstract}
Rooted liners of pot rose (Rosa L.) cultivars Meiferjac, Meigagul, Meighivon, Meishulo, Ruijef, Ruidodo, and Ruirosora were used to study the influence of cultivar and seasonal growing environment on growth and postharvest performance. Single-shoot plants were grown in controlled environment chambers simulating summer $\left(30^{\circ} \mathrm{C}\right.$ day/ $21{ }^{\circ} \mathrm{C}$ night cycle with a 14-hour photoperiod) and winter $\left(21^{\circ} \mathrm{C}\right.$ day/16 ${ }^{\circ} \mathrm{C}$ night cycle with a 10-hour photoperiod) greenhouse growing conditions. At flower developmental stage 2 (showing color, calyx reflexing, no petals reflexed), the plants were placed in a continuously lighted simulated interior evaluation room at $21 \pm 1^{\circ} \mathrm{C}$ under $15 \mu \mathrm{mol} \cdot \mathrm{m}^{-2} \cdot \mathrm{s}^{-1}$ photosynthetic photon flux from cool-white fluorescent lamps for postharvest evaluations. Plants had quicker flowering, smaller flower diameter, more compact growth, and smaller leaf area when grown under the summer environment compared to the winter environment. Most cultivars exhibited greater flower longevity on summer-grown plants when compared to winter-grown ones. 'Ruirosora' did not exhibit this difference due to exceptional longevity on winter-grown plants. Also, the use of single-shoot plants was shown to be a potentially useful way to increase replication in small growing environments such as growth chambers.
\end{abstract}

Miniature potted rose plants (Rosa L.) have increased in popularity in North America and are a major floriculture crop on the European market (Borch et al., 1995). Cultivars vary dramatically in postharvest performance. Halevy and Kofranek (1976) reported that 'Garnette' and 'Orange Margot Koster' plants had little bud and leaf abscission even at warm shipping temperatures $\left(21^{\circ} \mathrm{C}\right)$, whereas 'Pink Margot Koster' was severely injured. 'Meijikatar' and 'Confection' had more leaf abscission and/or yellowing than 'Meirutral', 'Meilarco', 'Shy Girl', and 'Ruired' after $4 \mathrm{~d}$ of simulated shipping at $8{ }^{\circ} \mathrm{C}$ and $7 \mathrm{~d}$ in a simulated interior environment (Clark et al., 1991). Flower longevity after simulated shipping $\left(4 \mathrm{~d}\right.$ at $\left.16^{\circ} \mathrm{C}\right)$

Received for publication 21 Oct. 2002. Accepted for publication 26 Mar. 2003. This manuscript includes research supported and conducted by the Texas Agricultural Experiment Station, The Texas A\&M Univ. System and is a portion of a Ph.D. dissertation submitted by José Antonio Saraiva Grossi. We acknowledge and thank CAPES (Federal Agency for Post-Graduate Education, Ministry of Education, Brazil) for providing the student scholarship for J. Grossi and Yoder Brothers, Barberton, Ohio, for supplying pot rose plants.

${ }^{1}$ Former Graduate Student. Current title and address: Adjunto Professor. Departamento de Fitotecnia, Universidade Federal de Viçosa, Viçosa, M.G., Brasil, 36571-000.

${ }^{2}$ Professor.

${ }^{3}$ Current address: Fischer USA, 2995 Wilderness Place, Ste. 102, Boulder, CO 80301. of 'Meirutral' plants was longer in an interior environment than 'Meijikatar' regardless of chemical treatments (Cushman et al., 1994). Müller et al. (1998) reported that, for the shortlived cultivars Parade Bronze, Parade Bianca, and Kordana Ice, $>50 \%$ of the flowers faded after $10 \mathrm{~d}$ in a controlled interior environment. On the contrary, the long-lived cultivars Parade Charming, Parade Dreaming, Parade Harmony, and Kordana Vanilla had $70 \%$ of the initial flowers after $20 \mathrm{~d}$. All of these studies were performed using plants with multiple flowering shoots.

The time of the year that a crop is grown may affect growth and flowering as well as the postharvest longevity of the crop once it is placed in an interior environment (Pemberton et al., 1997). Better flower quality, longer poststorage floral longevity and less poststorage leaf chlorosis were observed during summer for greenhouse-grown 'Meirutral' and 'Meijikatar' potted miniature roses when compared to winter-grown plants (Chen, 1990; Cushman et al., 1998). Rajapakse and Kelly (1994) reported less lower leaf yellowing after simulated shipping on 'Meijikatar' plants grown in the summer in comparison to plants grown in late spring. Borch et al. (1995) found a decrease in the number of wilted flowers after $18 \mathrm{~d}$ in an interior environment on summergrown 'Poulnye' and 'Poulvic' plants when compared to winter-grown plants. There was no difference for 'Pouloral' plants. Also, there was a lower incidence of Botrytis and fewer chlorotic flower buds on summer-grown plants when compared to winter-grown plants, despite the former having more flowers than the latter. Serek et al. (1995) found that leaves of 'Royal' plants summer-grown in California yellowed rapidly when the plants were placed in the dark. However, the dark treatment had no significant effect on leaf yellowing on plants winter-grown in Denmark under supplementary light.

In growth chamber studies, Kyalo et al. (1996) found improved postproduction longevity, more flowers, more compact growth and quicker flowering when plants were grown under summer-like conditions. However, those plants produced smaller and lighter-colored flowers than those under the winter-like environment. Monteiro et al. (2001) also found an interaction between cultivar and season with regards to postharvest flower longevity. 'Meijikatar' and Meirutral' had higher longevities if grown in spring/summer when compared to fall/winter-grown, whereas, 'Meidanclar', Meilarco', and 'Schobitet' did not show any difference. All of these studies were also performed using plants with multiple flowering shoots.

To facilitate further studies of seasonal postharvest responses, these studies were initiated to evaluate the effects of seasonal growing environments on the growth, flowering and postharvest performance of currently available potted rose cultivars. In addition, these studies were performed using growth chambers and single-shoot plants so that a method could be established that would provide easily reproducible growing environments and to reduce the complexity of multiple-shoot plants used in past studies.

\section{Material and Methods}

Rooted liners of miniature rose (Rosa L.) cultivars Meiferjac (Autumn Sunblaze ${ }^{\circledR}$ ), Meigagul (Gypsy Sunblaze ${ }^{\circledR}$ ), Meighivon (Snow Sunblaze ${ }^{\circledR}$ ), Meishulo (Salmon Sunblaze ${ }^{\circledR}$ ), Ruijef (Cherry Cupido ${ }^{\mathrm{TM}}$ ), Ruidodo (Favorite Cupido $^{\circledR}$ ), and Ruirosora (Sunrise Cupido ${ }^{\mathrm{TM}}$ ) produced by Yoder Brothers, in Parish, Fla., were received in Overton, Texas, on 22 Sept. 1999. Each liner consisted of three or four rooted cuttings and were kept in a fan-andpad cooled greenhouse in Overton. Each liner was separated into individual plants that were planted in $450-\mathrm{cm}^{3}(9-\mathrm{cm})$ square plastic pots in a peat: perlite (LC-1) (SunGro Horticulture, Bellevue, Wash.) growing medium on 24 Sept. 1999. The greenhouse was covered with $30 \%$ shade to provide light reduction leaving an average light intensity of $1025 \mu \mathrm{mol} \cdot \mathrm{m}^{-2} \cdot \mathrm{s}^{-1}$ photosynthetic photon flux $(P P F)$ at noon on a clear day. Greenhouse environmental control was set to start venting at $21^{\circ} \mathrm{C}$, and the average temperature was $26^{\circ} \mathrm{C}$ day $/ 22^{\circ} \mathrm{C}$ night.

Plants were fertilized with $200 \mathrm{mg} \cdot \mathrm{L}^{-1} \mathrm{~N}$ with $15 \mathrm{~N}-2.2 \mathrm{P}-12.4 \mathrm{~K}$ (Scotts-Sierra Horticultural Products Co., Marysville, Ohio) on a schedule of two feedings followed by one leaching and biweekly supplemented with $0.05 \mathrm{~g} \cdot \mathrm{L}^{-1}$ iron chelate DP (Miller Chemical $\&$ Fertilizer Corp., Hanover, Pa.). Plants were 
sprayed and drenched as needed for mite, insect, and disease control.

When the root system of each plant was well established in the pot (12 Oct. 1999), five plants of each cultivar were randomly selected and placed into each of two environment-controlled growth chambers at $22{ }^{\circ} \mathrm{C}$ with a 16-h photoperiod and average $P P F$ of $650 \mu \mathrm{mol} \cdot \mathrm{m}^{-2} \cdot \mathrm{s}^{-1}$ at the plant canopy height in both chambers. On 20 Oct. 1999, after a period of $8 \mathrm{~d}$ for plant acclimation in the growth chambers, each plant was pinched just above the third or fourth leaf from the base of the strongest growing shoot. All other shoots were removed where they joined the main stem. The growth chambers were then programmed to simulate summer-like or winterlike greenhouse growing conditions, at $30^{\circ} \mathrm{C}$ day $/ 21{ }^{\circ} \mathrm{C}$ night cycle with a 14 -h photoperiod, or $21{ }^{\circ} \mathrm{C}$ day $/ 16^{\circ} \mathrm{C}$ night cycle with a 10 -h photoperiod, respectively. The $P P F$ provided from cool-white fluorescent lamps averaged $650 \mu \mathrm{mol} \cdot \mathrm{m}^{-2} \cdot \mathrm{s}^{-1}$ at plant canopy height in both chambers. During the experiment, each plant was grown with a single flowering stem. This was accomplished by removing all but the strongest of the shoots that began growing after the pinch as they arose. When the flower on each plant reached developmental stage 2 [(Cushman et al., 1994) showing color, calyx reflexing, no petals reflexed], the plant was placed in a continuously lighted simulated interior evaluation room at $21 \pm 1{ }^{\circ} \mathrm{C}$ under $15 \mu \mathrm{mol} \cdot \mathrm{m}^{-2} \cdot \mathrm{s}^{-1} P P F$ from cool-white fluorescent lamps.

At flower developmental stage 2, we evaluated the length and number of nodes of the flowering shoot, and the time to flowering defined as the number of days between pinching the stem and reaching flower developmental stage 2 .

During the interior evaluation, flower diameter was measured at flower developmental stage 5 [(Cushman et al., 1994), full open]. Postproduction flower longevity was defined as the period from flower developmental stage 2 to the first day of flower developmental stage 6. Leaf area of the flowering shoot was measured on the first day of flower developmental stage 6 [(Cushman et al., 1994), postharvest life over, petal wilting or abscission] using a LI-COR Portable Area Meter model LI-3000 (Lincoln, Nebr.). Flower quality was rated as 1 for normally developed flowers, which opened fully with normal form and color, and then showed normal senescence with petal wilting. Rating 2 was given to flowers which opened, but exhibited deviations from normal form and/or color at any flower developmental stage. Rating 3 was given to flowers which abscised without opening or exhibited severe color or form deviations. Leaf abscission was rated on the first day of flower development stage 6 on a scale of 1 to $10(1=91 \%$ to $100 \%$ abscission and $10=0 \%$ to $10 \%$ abscission). Yellow leaves were included with the abscised leaves in assigning a rating as they fell quickly after yellowing.

This experiment was a $7 \times 2$ factorial $(7$ cultivars $\times 2$ simulated growing conditions) arranged within each chamber in a completely randomized block design, with five blocks, using one plant in each block. All the data were subjected to analysis of variance using SAS software, general linear model procedure (SAS Institute, 1987). Means were separated by Duncan's multiple range test at the $5 \%$ level of probability.

\section{Results and Discussion}

The flowering shoot length was influenced by growing environment and cultivar, but the number of nodes on the flowering shoot was influenced only by growing environment (Table 1). Both growth characteristics were greater under winter than summer growing conditions. Under winter growing conditions, the flowering shoot length was $\approx 50 \%$ taller and there were slightly more nodes than under summer growing conditions. 'Ruirosora' plants presented the longest flowering shoot while 'Ruidodo' plants had the shortest (Table 1). The leaf area of the flowering shoot was affected by the growing environment $\times$ cultivar interaction (Table 2). All cultivars except 'Meigagul' exhibited a larger leaf area under winter than summer growing conditions (comparisons not shown). Thus, plants under the winter growing environment were generally larger than plants grown under the summer environment by exhibiting the greater of these three evaluated growth characteristics. Kyalo et al. (1996) found that 'Meirutral' and 'Meijikatar' potted miniature roses grown under a simulated summer environment were more compact than plants grown under a simulated winter environment, and other studies have found greenhouse grown plants to be more compact in the spring or summer in comparison to winter (Borch et al., 1995; Clark et al., 1993), but the number of nodes was not counted in these studies.

All four evaluated flowering characteristics were affected by the growing environment $x$ cultivar interaction (Tables 2 and 3). The number of days for the flower on the single- stemmed plants to reach developmental stage 2 was greater under the winter compared to the summer growing environment for all cultivars (comparisons not shown) (Table 2). The time difference between growing environments ranged from 9 to $14.4 \mathrm{~d}$ on 'Meighivon' and 'Ruidodo' plants, respectively. Under the summer growing environment, 'Meiferjac' plants were the first to reach flower developmental stage 2. Under the winter environment, 'Meighivon' plants reached flower development stage 2 first (Table 2).

All the cultivars, except 'Ruidodo' and 'Ruirosora', exhibited greater flower longevity when plants were grown under a summer environment compared to a winter growing environment (Table 3). Similar flower longevities were observed between growing environments for those two cultivars. For cultivars where the flowers lasted longer on summer-grown plants, the longevity difference between growing environments ranged from $3.8 \mathrm{~d}$ for 'Meigagul' plants to $5.4 \mathrm{~d}$ for 'Ruijef' and 'Meishulo' plants. The average difference for flower longevity for that group of cultivars was $4.8 \mathrm{~d}$, representing an increase of $36 \%$ in flower longevity when the plants were grown under the simulated summer environment. Among all cultivars grown under the summer environment, 'Meiferjac' and 'Ruijef' exhibited the greatest flower longevity, and 'Meigagul' exhibited the shortest flower longevity, differing $8 \mathrm{~d}$ from the longest to the shortest lasting group. Under the winter growing environment, flowers from the 'Ruirosora' cultivar lasted the longest time, and flowers from 'Meighivon' and 'Meigagul' plants lasted the shortest time, differing $7 \mathrm{~d}$ from each group. Thus, for both growing conditions, 'Meigagul' plants exhibited the shortest flower longevity with a reduction of $28 \%$ ( $3.8 \mathrm{~d}$ ) on winter-grown plants compared to summer-grown ones (Table 3 ). Improved postharvest longevity on summergrown plants in comparison to winter-grown plants has also been observed in other studies

Table 1. Means of flowering shoot length, number of nodes on the flowering shoot, and leaf abscission rating ${ }^{z}$ of miniature rose plants affected by cultivar and growing environment. Summer-like consists of $30{ }^{\circ} \mathrm{C}$ day $/ 21{ }^{\circ} \mathrm{C}$ night and 14 -h photoperiod, and winter-like consists of $21^{\circ} \mathrm{C}$ day $/ 16^{\circ} \mathrm{C}$ night and $10-\mathrm{h}$ photoperiod.

\begin{tabular}{|c|c|c|c|}
\hline $\begin{array}{l}\text { Growing } \\
\text { environment }\end{array}$ & $\begin{array}{l}\text { Flower shoot } \\
\text { length }(\mathrm{cm})\end{array}$ & $\begin{array}{l}\text { No. of } \\
\text { nodes }\end{array}$ & $\begin{array}{c}\text { Leaf abscission } \\
\text { rating }^{2}\end{array}$ \\
\hline Winter-like & $17.9 \mathrm{a}$ & $8.3 \mathrm{a}$ & 10.0 \\
\hline Summer-like & $12.4 \mathrm{~b}$ & $7.6 \mathrm{~b}$ & 10.0 \\
\hline \multicolumn{4}{|l|}{ Cultivar } \\
\hline Meiferjac & $15.3 \mathrm{bc}$ & 7.8 & 10.0 \\
\hline Ruijef & $14.7 \mathrm{bcd}$ & 7.6 & 10.0 \\
\hline Ruirosora & $17.1 \mathrm{a}$ & 8.6 & 10.0 \\
\hline Meishulo & $13.9 \mathrm{~cd}$ & 8.1 & 10.0 \\
\hline Ruidodo & $13.5 \mathrm{~d}$ & 7.0 & 10.0 \\
\hline Meighivon & $15.9 \mathrm{ab}$ & 8.1 & 10.0 \\
\hline Meigagul & $15.5 \mathrm{abc}$ & 8.2 & 9.8 \\
\hline \multicolumn{4}{|c|}{ ANOVA F values } \\
\hline Environment (E) & $180.51^{* *}$ & $6.30^{*}$ & $0.00^{\mathrm{Ns}}$ \\
\hline Cultivar (C) & $5.17^{* *}$ & $2.00^{\mathrm{Ns}}$ & $1.96^{\mathrm{Ns}}$ \\
\hline $\mathrm{E} \times \mathrm{C}$ & $2.09^{\mathrm{Ns}}$ & $2.24^{\mathrm{Ns}}$ & $0.00^{\mathrm{Ns}}$ \\
\hline MSE & 2.917 & 1.307 & 0.029 \\
\hline
\end{tabular}


(Borch et al., 1995; Chen, 1990; Cushman et al., 1998; Kyalo et al., 1996; Monteiro et al., 2001; Rajapakse and Kelly, 1994; Serek et al., 1995). The variation of postharvest flowering longevity among cultivars has also been reported for miniature roses (Clark et al., 1991; Cushman et al., 1994; Halevy and Kofranek 1976; Müller et al., 1998). However, the postharvest flower longevity for the potted rose cultivars in the present study has not been previously reported.

For all cultivars, the flower diameter was larger under the winter than for the summer growing condition (comparisons not shown) (Table 3 ). On the average, the flower diameters were $1.2 \mathrm{~cm}$ greater under winter than under summer conditions. A similar flower diameter pattern was observed among all cultivars within each growing condition. No differences were found in flower diameter of 'Meirutral' and 'Meijikatar' miniature roses grown under simulated summer or winter growing environments (Kyalo et al., 1996).

The flower quality was the same for both growing environments, except for the 'Ruijef' and 'Meighivon' cultivars (comparisons not shown) (Table 3). Those two cultivars exhibited the lowest flower quality among all cultivars under the summer environment. 'Meighivon' plants exhibited the lowest flower quality of all cultivars under winter growing conditions. The lowest flower quality exhibited by the 'Meighivon' cultivar in both growing environments was due to the development of vegetative growing tissue associated with the stamens and the ovary on the flower. Chen (1990) found that 'Meijikatar' miniature rose plants exhibited better flower quality than 'Meirutral' under summer growing conditions, but the opposite was true under winter growing conditions.

Leaf abscission evaluated at the end of the flower longevity was not influenced by either cultivar or growing environment (Table 1). No cultivars exhibited any leaf abscission, except for 'Meigagul' plants, which had only $2 \%$ abscission. Postharvest leaf abscission differences in miniature roses have been reported due to cultivar (Chen, 1990), light conditions during production (Rajapakse and

Table 2. Means of number of days to reach flower development stage 2 and leaf area of the flowering shoot of miniature rose plants affected by cultivar and growing environment. Growing environment consists of summer-like conditions $\left(30^{\circ} \mathrm{C}\right.$ day $/ 21{ }^{\circ} \mathrm{C}$ night and 14 -h photoperiod) and winter-like conditions $\left(21{ }^{\circ} \mathrm{C}\right.$ day $/ 16^{\circ} \mathrm{C}$ night and 10 -h photoperiod).

\begin{tabular}{|c|c|c|c|c|}
\hline \multirow[b]{2}{*}{ Cultivar } & \multicolumn{2}{|c|}{ Days to flower stage 2} & \multicolumn{2}{|c|}{ Leaf area $\left(\mathrm{cm}^{2}\right)$} \\
\hline & Summer-like & Winter-like & Summer-like & Winter-like \\
\hline Meiferjac & $20.0 \mathrm{c}$ & $31.2 \mathrm{~cd}$ & $110.2 \mathrm{a}$ & $192.2 \mathrm{a}$ \\
\hline Ruijef & $22.0 \mathrm{abc}$ & $33.2 \mathrm{bc}$ & $76.2 \mathrm{~b}$ & $126.4 \mathrm{~b}$ \\
\hline Ruirosora & $21.8 \mathrm{abc}$ & $33.0 \mathrm{bc}$ & $65.4 \mathrm{bc}$ & $119.0 \mathrm{bc}$ \\
\hline Meishulo & $20.6 \mathrm{bc}$ & 32.6 bcd & $80.1 \mathrm{~b}$ & $129.8 \mathrm{~b}$ \\
\hline Ruidodo & $22.2 \mathrm{ab}$ & $36.6 \mathrm{a}$ & $49.7 \mathrm{c}$ & $89.9 \mathrm{~cd}$ \\
\hline Meighivon & $21.4 \mathrm{abc}$ & $30.4 \mathrm{~d}$ & $55.4 \mathrm{c}$ & $89.7 \mathrm{~cd}$ \\
\hline Meigagul & $23.0 \mathrm{a}$ & $34.4 \mathrm{ab}$ & $64.5 \mathrm{bc}$ & $61.7 \mathrm{~d}$ \\
\hline \multicolumn{5}{|c|}{ ANOVA F values } \\
\hline Environment (E) & \multicolumn{2}{|c|}{$857.11^{* *}$} & \multicolumn{2}{|c|}{$96.81^{* *}$} \\
\hline Cultivar (C) & \multicolumn{2}{|c|}{$7.31^{* *}$} & \multicolumn{2}{|c|}{$23.12^{* *}$} \\
\hline $\mathrm{E} \times \mathrm{C}$ & \multicolumn{2}{|c|}{$2.35^{*}$} & \multicolumn{2}{|c|}{$3.33^{* *}$} \\
\hline MSE & \multicolumn{2}{|c|}{2.694} & \multicolumn{2}{|c|}{0.037} \\
\hline
\end{tabular}

Ns, *, ${ }^{* *}$ Nonsignificant or significant at $P=0.05$ or 0.01 , respectively. Means separation within columns followed by the same letter are not different according to Duncan's multiple range test at $P=0.05$.

Kelly, 1994), and time of year and location of production (Serek et al., 1995). Whether the cultivars used in the present study are resistant to leaf yellowing during the postharvest period or the conditions in the present study were not conducive to the development of this condition is not known.

In other growth chamber studies, differences in postharvest floral longevity due to preharvest growing environment were found using multiple-stemmed plants (Kyalo et al., 1996). In the present study, differences in postharvest floral longevity due to preharvest growing environment were also found using the same equipment used by Kyalo et al. (1996), except that single-stemmed plants were used. Although cultivars were different between the two studies, the present study suggests that single-stemmed potted miniature rose plants could be useful for studying postharvest responses to growing environment. The reduced plant size facilitates the use of small growing environments such as growth chambers by allowing a larger number of experimental units than would otherwise be possible.

The present study has increased our knowledge of how the floral longevity of different potted miniature rose cultivars responds to the preharvest growing environment. When considering other studies that have measured the postharvest longevity of individual flowers in response to seasonal growing environment so that direct comparisons can be made, we found plants of 'Ruirosora' to be unique in that flower longevity remained as exceptional after growing under winter-like conditions as that on plants grown under summer-like conditions (Table 3). 'Ruirosora' flowers had the greatest longevity on winter-grown plants in the present study with $20.6 \mathrm{~d}$, whereas the greatest longevity on winter-grown plants was 10 and $11 \mathrm{~d}$ for studies by Kyalo et al. (1996) and Monteiro et al. (2001), respectively. Exceptional floral longevity on winter-grown plants most likely exists for other cultivars not used in these studies as the number of cultivars subjected to such experimental regimens has been quite limited. Understanding why this response exists is of strong interest for future studies.

Table 3. Means of flower longevity, flower diameter, and flower quality rating ${ }^{2}$ of miniature rose plants in the postharvest room affected by cultivar and growing environment. Growing environment consists of summer-like conditions $\left(30^{\circ} \mathrm{C}\right.$ day $/ 21^{\circ} \mathrm{C}$ night and 14 -h photoperiod) and winterlike conditions $\left(21^{\circ} \mathrm{C}\right.$ day/ $16^{\circ} \mathrm{C}$ night and 10 -h photoperiod).

\begin{tabular}{|c|c|c|c|c|c|c|c|}
\hline \multirow[b]{2}{*}{ Cultivar } & \multicolumn{2}{|c|}{ Flower diam $(\mathrm{cm})$} & \multirow{2}{*}{$\begin{array}{l}\text { Comparison between } \\
\text { growing environments }\end{array}$} & \multicolumn{2}{|c|}{ Flower diam $(\mathrm{cm})$} & \multicolumn{2}{|c|}{ Flower quality rating ${ }^{2}$} \\
\hline & Summer-like & Winter-like & & Summer-like & Winter-like & Summer-like & Winter-like \\
\hline Meiferjac & $22.4 \mathrm{a}$ & $17.4 \mathrm{~b}$ & $*$ & $3.2 \mathrm{a}$ & $4.5 \mathrm{ab}$ & $1.0 \mathrm{~d}$ & $1.0 \mathrm{~b}$ \\
\hline Ruijef & $21.8 \mathrm{a}$ & $16.4 \mathrm{~b}$ & $*$ & $2.3 \mathrm{c}$ & $3.7 \mathrm{~d}$ & $2.0 \mathrm{~b}$ & $1.0 \mathrm{~b}$ \\
\hline Ruirosora & $18.8 \mathrm{~b}$ & $20.6 \mathrm{a}$ & NS & $3.3 \mathrm{a}$ & $4.8 \mathrm{a}$ & $1.0 \mathrm{~d}$ & $1.0 \mathrm{~b}$ \\
\hline Meishulo & $17.4 \mathrm{bc}$ & $12.0 \mathrm{~cd}$ & $*$ & $3.1 \mathrm{a}$ & $4.2 \mathrm{bc}$ & $1.0 \mathrm{~d}$ & $1.0 \mathrm{~b}$ \\
\hline Ruidodo & $16.4 \mathrm{bcd}$ & $14.6 \mathrm{bc}$ & NS & $2.8 \mathrm{~b}$ & $3.9 \mathrm{~cd}$ & $1.6 \mathrm{c}$ & $1.0 \mathrm{~b}$ \\
\hline Meighivon & $15.0 \mathrm{~cd}$ & $10.6 \mathrm{~d}$ & $*$ & $3.3 \mathrm{a}$ & $4.1 \mathrm{~cd}$ & $3.0 \mathrm{a}$ & $1.6 \mathrm{a}$ \\
\hline Meigagul & $13.8 \mathrm{~d}$ & $10.0 \mathrm{~d}$ & $*$ & $3.3 \mathrm{a}$ & $4.3 \mathrm{bc}$ & $1.0 \mathrm{~d}$ & $1.0 \mathrm{~b}$ \\
\hline & & & ANOVA F values & & & & \\
\hline Environment (E) & \multicolumn{2}{|c|}{$41.06^{* *}$} & & \multicolumn{2}{|c|}{$411.36^{* *}$} & \multicolumn{2}{|c|}{$74.55^{* *}$} \\
\hline Cultivar (C) & \multicolumn{2}{|c|}{$22.33^{* *}$} & & \multicolumn{2}{|c|}{$19.09^{* *}$} & \multicolumn{2}{|c|}{$54.12^{* *}$} \\
\hline $\mathrm{E} \times \mathrm{C}$ & \multicolumn{2}{|c|}{$3.44^{* *}$} & & \multicolumn{2}{|c|}{$3.04^{*}$} & \multicolumn{2}{|c|}{$19.66^{* * *}$} \\
\hline MSE & \multicolumn{2}{|c|}{5.010} & & \multicolumn{2}{|c|}{0.056} & \multicolumn{2}{|c|}{0.043} \\
\hline
\end{tabular}

${ }^{\mathrm{z}} 1$ = Flowers developed normally; 2 = Flowers opened but had problems with color and/or form; $3=$ Flowers abscised without opening or exhibited severe color and/or form problems.

ss, ${ }^{*}, *$ Nonsignificant or significant at $P=0.05$ or 0.01 , respectively. Means separation within columns followed by the same letter are not different according to Duncan's multiple range test at $P=0.05$. 


\section{Literature Cited}

Borch, K., M.H. Williams, and L. Hoyer. 1995. Influence of simulated transport on postharvest longevity of three cultivars of miniature rose. Acta Hort. 424:175-180.

Chen, L.C. 1990. Growth regulator reversal of simulated high temperature shipping effects on flower senescence and leaf abscission. Dept. of Hort. Sci. MS Thesis, Texas A\&M Univ, College Station.

Clark, D.G., J.W. Kelly, and H.B. Pemberton. 1991. Postharvest quality characteristics of cultivars of potted rose in response to holding conditions and cytokinins. HortScience 26:1195-1197.

Clark, D.G., J.W. Kelly, and N.C. Rajapakse. 1993. Production and postharvest characteristics of Rosa hybrida L. 'Meijikatar' grown in pots under carbon dioxide enrichment. J. Amer. Soc. Hort. Sci. 118:613-617.
Cushman, L.C., H.B. Pemberton, and J.W. Kelly. 1994. Cultivar, flower stage, silver thiosulfate, and BAinteractions affect performance of potted miniature roses. HortScience 29:805-808.

Cushman,L.C., H.B. Pemberton, J.C. Miller, Jr., and J.W. Kelly. 1998. Interactions of flower stage, cultivar, and shipping temperature and duration affect pot rose performance. HortScience 33: 736-740.

Halevy, A.H. and A.M. Kofranek. 1976. The prevention of flower bud and leaf abscission in po roses during simulated transport. J. Amer. Soc. Hort. Sci. 101:658-660.

Kyalo, T.M., H.B. Pemberton, and J.M. Zajicek. 1996. Seasonal growing environment affects quality characteristics and postproduction longevity of potted miniature roses. HortScience $31: 120-122$.
Monteiro, J.A., T.A. Nell, and J.E. Barrett. 2001 Postproduction of potted miniature rose: Flower respiration and single flower longevity. J. Amer. Soc. Hort. Sci. 126:134-139.

Müller, R., A.S. Andersen, and M. Serek. 1998. Differences in display life of miniature potted roses (Rosa hybrida L.). Scientia Hort. 76:59-71.

Pemberton, H.B., J.W. Kelly, and J. Ferare. 1997. Production of pot roses. Timber Press, Portland.

Rajapakse, N.C. and J.W. Kelly. 1994. Influence of spectral filters on growth and postharvest quality of potted miniature roses. Scientia Hort. 56 : 245-256.

SAS Institute. 1987. SAS/STA: Guide for personal computers, Version 6. SAS Inst., Cary, N.C.

Serek, M.,E.C. Sisler, and M.S. Reid. 1995. Ethylene and the postharvest performance of miniature roses. Acta Hort. 424:145-149. 